\title{
The relevance of mixed methods for network analysis in tourism and hospitality research
}

Article

Accepted Version

Mariani, M. and Baggio, R. (2020) The relevance of mixed methods for network analysis in tourism and hospitality research. International Journal of Contemporary Hospitality Management, 32 (4). pp. 1643-1673. ISSN 0959-6119 doi: https://doi.org/10.1108//JCHM-04-2019-0378 Available at https://centaur.reading.ac.uk/87567/

It is advisable to refer to the publisher's version if you intend to cite from the work. See Guidance on citing.

To link to this article DOI: http://dx.doi.org/10.1108/IJCHM-04-2019-0378

Publisher: Emerald

All outputs in CentAUR are protected by Intellectual Property Rights law, including copyright law. Copyright and IPR is retained by the creators or other copyright holders. Terms and conditions for use of this material are defined in the End User Agreement.

www.reading.ac.uk/centaur 
Central Archive at the University of Reading

Reading's research outputs online 


\title{
The relevance of Mixed Methods for Network Analysis in Tourism and Hospitality Research
}

\begin{abstract}
Purpose - Taking stock of extant hospitality and tourism research using social network analysis approaches, this work highlights why using either quantitative or qualitative approaches to examine social networks can be misleading and generate potentially biased findings. Indeed, purely qualitative and purely quantitative studies display limitations. This study provides methodological insights by suggesting that mixed methods can be suitably used, depending on the specific research questions.

Design/methodology/approach - The study consists of an analysis and critical discussion of the methods employed in a number of articles leveraging social network approaches to study social networks in tourism and hospitality. We describe benefits and limitations of each method Papers considered are examined based on a number of aspects.

Findings -More than a half of the works classified as network studies adopt quantitative designs and quantitative methods including statistical analyses and observational data. Mixed methods study are a minority and they are almost never labelled as mixed methods. A relevant portion of qualitative studies increasingly embeds a number of rudimentary statistical analyses. With an example, we also discuss that purely quantitative or purely qualitative methods can lead to discrepant results and thus we encourage scholars to embrace mixed method research designs such as Explanatory or Exploratory Sequential Designs. Advanced researchers might attempt in the future to embrace transformative, embedded or multiphase mixed methods.
\end{abstract}

Research limitations/implications - This work is based on academic articles and research published before 2019. A rich research agenda is designed.

Originality/value - This study contributes to explore the way social networks have been dealt with in tourism and hospitality research so far, by advancing a proposal to adopt mixed methods in the form of explanatory or exploratory sequential designs. To the best of our knowledge, it is the first work addressing methodological pitfalls in extant network based research within the tourism and hospitality domain.

Keywords: Network analysis; Quantitative methods; Qualitative methods; Mixed methods; Hospitality; Tourism. 


\section{Introduction}

In the contemporary world networks are ubiquitous and are playing an increasingly relevant role in a number of business domains (Snehota \& Hakansson, 1995). The advent, consolidation and development of ICTs and digital technologies have intensified the speed at which both physical and digital networks are formed and modified over time (Mariani, et al., 2014).

Tourism destinations, conceived as complex systems encompassing tangible and intangible resources and assets are certainly not an exception. In a tourism destination the interdependence between socio-economic actors (be them individuals or organizations) is an essential feature (Björk \& Virtanen, 2005) and implies intense collaboration to generate valuable and meaningful tourism products, services and experiences, and to foster innovation (Bramwell \& Sharman, 1999; Mariani, Buhalis, Longhi and Vitouladiti, 2014; Novelli et al., 2006).

Over the last 15 years, and increasingly over the last decade, tourism and hospitality scholars have adopted network science approaches to the study of networks (be them physical or digital) in the tourism, travel and hospitality field (Baggio, 2017; Baggio et al., 2010; Casanueva et al., 2016). Different research designs and methods have been deployed including quantitative and qualitative research designs and methods (Creswell, 2003, 2014; Creswell and Plano Clark, 2007). However, no structured reflection has been carried out (and thus no knowledge has been developed) on the research designs and methods actually deployed in tourism and hospitality network studies, by emphasizing features, merits, and challenges as well as suitability in relation to the object of this study.

This work addresses this knowledge gap and contributes to the methodology literature in three ways. First, taking stock of extant hospitality and tourism research adopting a social network approach analyzed by means of a systematic quantitative literature review (SQLR), it identifies the most common research designs and methods distinguishing qualitative, quantitative and mixed methods. Second, it triggers a reflection about the relative strengths and weaknesses, advantages and disadvantages, and suitability of each approach (purely quantitative, purely qualitative, mixed methods). More specifically it highlights that using either quantitative or qualitative approaches to describe and investigate tourism networks can be misleading and generate potentially biased findings. Third, it offers a methodological insight suggesting that there is a third way in network science applied to the hospitality and tourism domain, reconciling and juxtaposing the quantitative and the qualitative research designs and methods. This has been adopted in a very limited number of tourism and hospitality studies conducted so far. We suggest that mixed methods including Explanatory Sequential Designs 
or Exploratory Sequential Designs can be suitably used, depending on the research questions and the specific philosophical worldviews (and epistemological stances) adopted by the researchers: post-positivist in the former case and constructivist in the latter case.

To make the aforementioned contributions, the paper is organized as follows: the second section offers a literature review focusing on the relevance and significance of network science approaches to the study of tourism and hospitality, and briefly introduces some of the methodological approaches that (at first sight and before the systematic quantitative literature review) seem to have been adopted. In the third paragraph we illustrate the data and methodology used. The fourth section reports the findings and the fifth discusses them in light of an emblematic example. The sixth and last section offers conclusions and a research agenda.

\section{Literature review}

\subsection{Network science approaches to the study of tourism and hospitality}

Networks are everywhere in the contemporary world and have played historically a relevant role in a number of different domains including science, arts and, obviously, business (Mulkay et al. 1975; Sedita, 2008; Snehota \& Hakansson, 1995).

Tourism is a network-based industry par excellence: namely, a domain in which interdependence is essential (Björk \& Virtanen, 2005) and collaborative or cooperative practices between different socio-economic actors within a destination are crucial for creating tourism products, services and experiences, and fostering innovation (Bramwell \& Sharman, 1999; Czakon et al., 2019; Kylänen \& Mariani, 2014; Mariani, 2016; Mariani \& Giorgio, 2017; Novelli et al., 2006).

Furthermore, networks are at the heart of collective action. Many of the 'tourism resources' (tangible and intangible) typically belong to the host community residing in the destination and are deployed conjointly to attract tourists and visitors to the destination and serve them. A collective action does not necessarily require an interlinked set of organisations, but when resources (both financial and human) are scarce and decisions related to tourism are mainly made by public bodies, a network of interested stakeholders can be highly effective (Dredge, 2005, 2006).

Thus, a network perspective can offer several useful outcomes for tourism studies and also for the hospitality enterprises that operate in a networked destination. It provides a means of counting, mapping and analyzing the patterns of connections between the elements of a tourism system, modelled as an ensemble of distinct individual and organizational actors (the 
nodes of the network), connected by the relationships existing between them (the links or edges) (Baggio et al., 2010).

The application of network science in the focal domain, after a late and slow start, is generating a growing number of works as it is increasingly clear that network science methodological approaches are able to provide interesting and useful outcomes, insights and implications for both theory and practice. They provide better ways to improve the level of understanding of the observed phenomena and offer efficient and effective tools for governing organizations and destinations (Baggio, 2017; Casanueva et al., 2016; van der Zee \& Vanneste, 2015).

While from an ontological perspective it is clear what a tourism network is about (i.e., a number of different social actors that interact with each other), different epistemological stances have been embraced so far in the way researchers can gain knowledge about the phenomenon under study (i.e. networked tourism and hospitality economic and social actors).

Here it appears that of the four epistemological perspectives typically deployed in social sciences (Creswell, 2003, 2014; Hughes, 1997) - namely postpositivism, constructivism, transformative, and pragmatism - the two most adopted are the postpositivist one (Phillips and Burbules, 2000; Smith, 1983) and the constructivist one (Crotty, 1998).

The post-positivist stance derives from the positivist one that recognizes that the researcher is relatively independent from the phenomenon investigated and that the latter can be studied objectively as it is separated from the researcher (e.g., Durkheim, 1982; Lazarsfeld and Henry, 1966, 1972). Post-positivism represents an advancement of positivism (Phillips and Burbules, 2000; Smith, 1983) in that researchers acknowledge to a certain extent that their previous knowledge and background might affect the way they observe the phenomenon which still is considered as objective (Kuhn, 1962; Popper, 1959). We might argue that the field of 'mathematical sociology' was triggered by a post-positivist epistemological approach to sociology (Coleman, 1964; Fararo 1963; Lazarsfeld \& Henry, 1966; Rapoport, 1957) that has translated ultimately into the emergence of quantitative research designs and methods to deal with social and economic networks: the 'quantitative' social network analysis as we know it today (Freeman, 2004). Consequently, the network phenomenon in tourism can be understood by means of objective and quantitative measures that the researcher can apply to the analyzed network, as clear in a number of works (Baggio, 2017; Baggio et al., 2010; Baggio \& Cooper, 2010; Scott et al., 2008).

The constructivist stance posits that there is interdependence between the researcher and the phenomenon under scrutiny and that knowledge is about human made constructions of 
the phenomenon under study (e.g., Crotty, 1998; Gadamer, 1960, 1975). To comply with constructivist epistemological stances, researchers adopt typically qualitative designs. such as phenomenology, narrative research, case studies (Eisenhardt \& Graebner, 2007; Yin, 2009), grounded theory (Gioia, 2013), ethnographic approaches (e.g., Van Maanen, 1979). Accordingly, the social network phenomenon in the tourism field has been understood by means of inter-subjective communication between the researcher and the actors of the network through qualitative designs such as phenomenology, narrative research, case studies, grounded theory, ethnographic approaches (e.g., Cohen \& Cohen, 2012; Kimbu \& Ngoasong, 2013; March \& Wilkinson, 2009).

That said, it seems that tourism and hospitality scholars interested in network studies are increasingly adopting a pragmatism epistemological stance (Cherryholmes, 1992), whereby scholars put the research problem at the center of their analyses and deploy all the methodological approaches and data available to comprehend the problem (Rossman \& Wilson, 1985). A very few studies in tourism seem to adopt this approach, such as the one of Czernek-Marszałek (2019) that adopts a mixed-method approach to study the Polish tourism area of Wisła and generates measures of centrality to identify the least and most engaged cooperators in the area and uses interviews with members of the Wisła Tourism Organization to get a more nuanced understanding of the phenomenon under scrutiny.

\subsection{Methodological approaches to the study of networks in tourism and hospitality}

Building on Creswell (2003, 2014), we can broadly distinguish three specific research methods that encompass differentiated forms of data collection, analyses and interpretations.

Typically, quantitative methods display a predetermined nature and rely on instrument-based questions; they make use of attitude, observational, census and performance data and analyze and interpret them by means of statistical analyses.

Qualitative methods exhibit a more emergent nature and rely on open-ended questions; they make use of observation, interview, document and audiovisual data and analyze them by means of text and image analyses used to interpret them through themes and patterns.

Mixed methods display both a predetermined and emergent nature and rely on both open- and closed-ended questions; they make use of multiple forms of data that could include attitude, observational, census, performance, observation, interview, document and audiovisual data and analyze them by means of both statistical and text analyses. Eventually the interpretation happens across databases. A synthesis of these methods is reported in Table 1: 


\begin{tabular}{|c|c|c|}
\hline Quantitative methods & Mixed methods & Qualitative methods \\
\hline Pre-determined & $\begin{array}{l}\text { Both predetermined and } \\
\text { emerging methods }\end{array}$ & Emerging methods \\
\hline Instrument based questions & $\begin{array}{l}\text { Both open- and closed- } \\
\text { ended questions }\end{array}$ & Open-ended questions \\
\hline $\begin{array}{l}\text { Performance data, attitude } \\
\text { data, observational data and } \\
\text { census data }\end{array}$ & $\begin{array}{l}\text { Multiple forms of data } \\
\text { drawing on all possibilities }\end{array}$ & $\begin{array}{l}\text { Interview data, observation } \\
\text { data, document data and } \\
\text { audiovisual data }\end{array}$ \\
\hline Statistical analysis & Statistical and text analysis & Text and image analysis \\
\hline Statistical interpretation & $\begin{array}{l}\text { Across database } \\
\text { interpretation }\end{array}$ & $\begin{array}{l}\text { Themes, patterns } \\
\text { interpretation }\end{array}$ \\
\hline
\end{tabular}

Table 1 - Quantitative, mixed and qualitative methods (Source: Creswell, 2014)

As suggested by other scholars investigating contexts other than tourism (Bellotti, 2014), mixed methods allow a deeper and more realistic understanding of the phenomenon examined, being at an intermediate level of different social mechanisms such as homophily, intermediation and transitivity. In one of her empirical studies, Bellotti (2014) analyzes the collaboration strategies in the field of philosophical research in Italy to win funded projects. This study combines a quantitative analysis based on archive sources first and then makes a qualitative analysis of the narratives contained in the projects themselves. Through this triangulation it is possible to observe the existence of common mechanisms, cohesion and brokerage that explain the observed dynamics and their legitimacy. Through the concept of 'social mechanisms' this brings to the conceptualization of mixed methods in the network analysis.

In their edited book on mixed methods in social network research, Hollstein \& Dominguez (2014) showcase different contributions pertaining to applications of mixed methods in diverse fields (e.g., social networks and fertility in the German context, innovation networks in global networked organizations. The book also suggests that advanced mixed methods approaches could be adopted, such as fuzzy-set analysis of network data, leveraging from text networks to narrative actor networks, personal network visualizations combined with interviews, simulations.

The use of specific network analysis methods is a relatively new phenomenon in tourism and hospitality (see Baggio 2017; van der Zee \& Vanneste, 2015). The pioneering research using network analysis approaches to tourism can be grouped into two different clusters. The first cluster includes scholars interested in tourism policy issues related to networks that have adopted prevalently qualitative techniques (e.g. Dredge, 2005, 2006). The second cluster 
comprises scholars interested in the structure and properties of tourism destination networks that have adopted prevalently quantitative techniques (e.g., Baggio et al., 2010).

The first cluster of studies, after an identification of the relevant actors in the network and an exploratory detection of their connections, uses mainly open-ended interviews with the relevant stakeholders and text analysis of documents. The relationships between individual and organizational actors and the main groups of actors are examined mostly using text analysis (including quotes from open-ended interviews) and the interpretation of data is mainly driven by the identification of themes and patterns (see Dredge, 2005, 2006).

The second cluster of studies mainly collects observational and census data by means of questionnaires, ad-hoc survey instruments and structured interviews with the relevant stakeholders. The relationships between individual and organizational actors and the main groups of actors are examined mostly using network analytical metrics such as centrality, density, and others (Baggio et al., 2010; Christopoulos \& Aubke, 2014). Apparently, the pioneering group of scholars, conducting studies that could be related to this quantitative stream (Baggio, 2007; Baggio et al., 2010; Scott et al., 2008), approached networks in tourism and hospitality based on knowledge developed in other disciplines and namely in hard sciences and mathematical sociology (Coleman, 1964; Fararo 1963; Lazarsfeld \& Henry, 1966; Rapoport, 1957). As such they had a preference for quantitative statistical tools to assess different networks' properties as well as static and dynamic features (Barabási, 2016; da Fontoura Costa et al., 2007).

Generally, it should be observed that there is not a stark dichotomy between the two clusters. For instance, as far as data is concerned, even studies of the second group (i.e., quantitative research) could complement observational data with archival data (companies' records and boards etc.) and, occasionally, data from interviews with key informants.

Overall, a number of good and updated literature reviews have been conducted on the use of network analysis in the tourism and hospitality domain (Baggio, 2017; Casanueva et al., 2016; Heidari et al., 2018; Merinero-Rodríguez \& Pulido-Fernández, 2016; van der Zee \& Vanneste, 2015). However, they mainly focus on the content of the examined relationships, rather than on the methods used in the studies. The aim of the present work is therefore to bridge this gap and disentangle the methodological approaches adopted to the study of networks in tourism and hospitality in and beyond the earliest studies commented above, in order to draw a comprehensive and granular picture of the methods adopted in the focal body of literature. 


\section{Methods}

As the major purpose of this paper is to gain a thorough understanding of the research methods and wider methodological approaches deployed in extant tourism and hospitality research embracing a network science perspective, we carried out a purposeful systematic quantitative systematic literature review (SQLR) of academic articles indexed in the Scopus database. SQLRs have been increasingly adopted in the wider social sciences (Mariani and Borghi, 2019) and in hospitality and tourism in particular (e.g. Law et al. 2016; Mariani et al., 2018) to gain a broad and in depth understanding of major research themes and gaps. In this case the SQLR is thought not as an end in itself but as a means of garnering relevant insights to develop an informed a robust discussion about methodological aspects.

The dimensions used to analyse methodological aspects are: 1) nature of the study; 2) research design; 3) methods adopted in the study; 4) sources of the data; 5) type and nature of the network analysed; 6) types and nature of the nodes of the network; 7) size of the network; 8) analysis techniques adopted in quantitative studies; 9) reporting and visualization tools. These dimensions allowed us to identify the major methodological features in extant hospitality and management network literature and make sense of potential methodological knowledge gaps, development needs and promising avenues for further research.

\subsection{Data}

Data was gathered from Scopus due to its wide coverage of academic published work in the social sciences in general and hospitality and tourism in particular. Scopus is one of the most comprehensive sources of scientific articles in the social sciences (Vieira and Gomes, 2009). With its more than 22,800 titles from over 5,000 international publishers, Scopus is considered one of the most comprehensive repositories of the world's research outputs. Overall, the use of this database ensures the reliability, validity and timeliness of the articles retrieved (Law et al., 2016; Mariani et al., 2018). A robustness analysis using Web of Science has suggested that Scopus covers everything that is indexed in Web of Science in the relevant research domain. As a consequence, Scopus was deemed to be effective and comprehensive for our aims. The data used for this SQLR was collected in January 2019, thus covering virtually every item indexed until the end of 2018.

We developed and embraced a few search criteria to sample the relevant articles. First, only full-length articles were included, leaving outside of our research books, book chapters 
and conference papers. Secondly, articles not related to the relevant domains (i.e. hospitality and tourism) were excluded.

In order to come up with the target population and sample, we deployed different sets of keywords that were used to run search queries in Scopus. First, we searched the keywords 'Network*' on the database. Second, we narrowed down our target population to look for works related to 'network analys*' related to the hospitality and tourism areas by leveraging the following searches matching: 1) 'network analys*' and 'touris*';2) 'network analys*' and 'hospitality'; 3) 'network analys*' and 'hotel*'; 4) 'network analys*' and 'guest*'; 5) 'network analys*' and 'travel*'; 6) 'network analys*' and 'leisure'; 7) 'network analys*' and 'festival*'.

Overall, searches using the aforementioned keywords in the titles, abstracts and keywords yielded 1,089 articles over the time span considered. Each individual abstract has then been manually inspected to drill down the relevant works for our analysis. The manual inspection was carried out by two experienced researchers independently on the population of articles stemming from the queries. Afterwards, the researchers compared their lists of articles and, given an inter-rater agreement of about $97 \%$, they agreed on the relevant sample of articles. The final dataset includes 145 articles (the full list is included in the appendix). The criteria used and the outcomes of the scanning process deployed provided the distribution shown in Table 2:

Table 2 Criteria used for the analysis of the papers and results

\begin{tabular}{|c|c|}
\hline Criteria & Papers distribution \\
\hline Type of paper & empirical 91.0\%; reviews or conceptual 9.0\% \\
\hline Research design & qualitative $22.3 \%$; quantitative $65.3 \%$; mixed $12.4 \%$ \\
\hline Research methods & $\begin{array}{l}\text { basic measurements } 71.4 \% \text {; advanced structural } \\
\text { analysis/simulations } 28.6 \%\end{array}$ \\
\hline $\begin{array}{l}\text { Type and nature of the } \\
\text { network(s) }\end{array}$ & symmetric $64.9 \%$; directed $28.4 \%$; bipartite $6.8 \%$ \\
\hline Types and nature of the nodes & $\begin{array}{l}\text { organizations } 39.8 \% \text {; individuals } 11.1 \% \text {; papers } 11.1 \% \text {; } \\
\text { locations/attractions } 19.4 \% \text {; others } 18.5 \%\end{array}$ \\
\hline $\begin{array}{l}\text { Network order (number of } \\
\text { nodes) }\end{array}$ & $\begin{array}{l}\text { large (>1000 nodes) 18.9\%; medium (100-1000 nodes) 19.8\%; } \\
\text { small (<100 nodes) } 61.3 \%\end{array}$ \\
\hline Reporting and visualization tools & Ucinet $49.2 \%$; other software packages $36.1 \%$; scripts $14.9 \%$ \\
\hline
\end{tabular}

\section{Findings}

Our analysis shows that the number of scientific works that examine networks as main topic in tourism and hospitality literature is slowly but steadily growing over time (see Figure 1). 


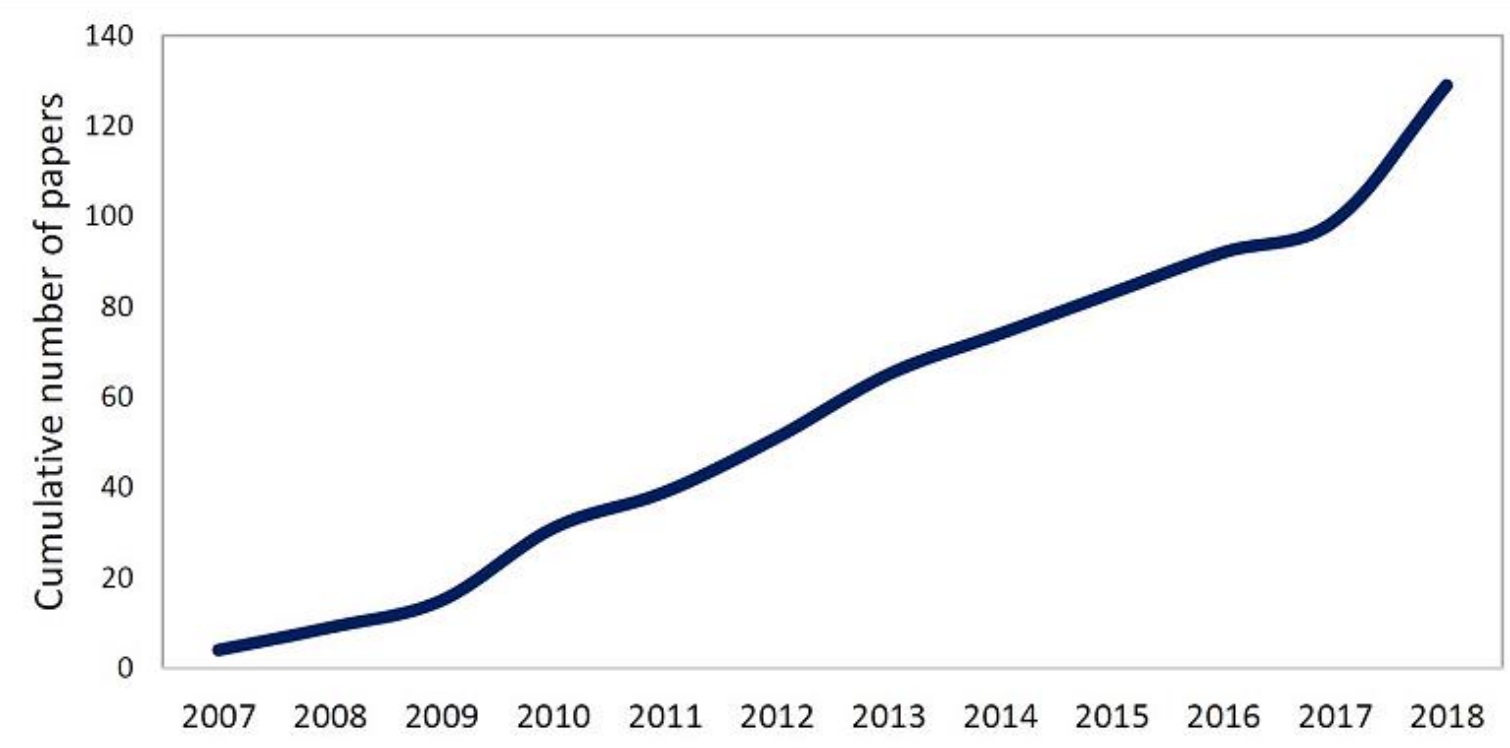

Figure 1 Cumulative number of 'network' papers in hospitality and tourism in the last 10 years (source: Authors' elaboration)

The large majority (75.9\%) of the works are of empirical nature, i.e., they use data collected in the field as sources for the study. The size of the networks studied is relatively small and only $22.8 \%$ use networks that contain more than one thousand nodes (e.g., Baggio \& Cooper, 2010; Racherla \& Hu, 2010; Raisi et al., 2018). This might look surprising in a period when a significant buzz is made around the possibility to leverage 'big' data actually available in the sector (e.g., Mariani et al., 2018; Mariani, 2019). However, despite the availability of more sophisticated data retrieval, processing, analysis and reporting and visualization tools and techniques, studies using big data analytics techniques are relatively scant in the hospitality and tourism literature. On the other hand, since a large proportion of the studies $(49.4 \%)$ is focussed on individual tourism destinations and considers organizations (companies, associations, public bodies etc.) as nodes (e.g., Edwards et al., 2017; Scott et al., 2008), the reviewed works do not include large tourism systems encompassing entire countries or even multiple countries.

About 55\% (54.5\%) of the publications adopt quantitative designs and methods, while $36.5 \%$ adopt mostly a qualitative approach. The remainder (9.0\%) deploys a mixed methods approach. It must be noted that many qualitative studies also adopt a few very elementary quantitative measures such as counts of nodes and links or connectivity density thus making purely quantitative and purely qualitative methods the poles of a continuum along the actual publications spectrum. 
Most of the networks analysed (46.4\%) are binary (unweighted) symmetric networks or are reduced to that configuration with different techniques (unweighting or dichotomizing the links' values). The analysis techniques are generally (69.6\%) quite basic. They entail a calculation of basic nodal centralities, average values of their values or global quantities (diameter, link density, or degree distributions). Relatively fewer studies use more advanced methods such as investigations on the mesoscopic structure of the network (components, communities or hierarchies) or employ spectral analysis. A handful of them also perform some numerical simulations to describe dynamic processes (information spreading or opinion formation) and propose some forms of optimization of the network with respect to such processes.

The major reason why most of the quantitative analyses are rather standard is that the software used for the analyses is standard as well. Most of the studies that explicitly name a software application, rely on standard software packages such as Ucinet (the most used) (see for instance Edwards et al., 2017; Scott et al., 2008; Timur \& Getz, 2008; Van der Zee \& Bertocchi, 2018), Gephi (Ghahramani \& Khalilzadeh, 2018; Luthe et al., 2012; Raisi et al., 2018) or Pajek (e.g., Éber et al., 2018; Racherla \& Hu, 2010; Sainaghi et al., 2019). Only a small proportion (17\%) employ some programming language with its libraries (mostly Python and Networkx) and a 'custom' made script (e.g., Baggio \& Scaglione, 2018; Éber et al., 2018).

Here, a significant knowledge gap in computer programming and coding skills exerts a detrimental impact on the development of novel analysis methods and informs the research methodology agenda, provided that standard packages usually lack many of the features that would be required for deeper or more sophisticated analyses.

\section{Discussion}

Several issues emerge from the findings. First, the analysis of the focal literature seems to witness the emergence and consolidation of a mainstream quantitative methodological approach to the study of networks in tourism and hospitality that was pioneered by several scholars and is rooted in mathematical sociology (Coleman, 1964; Fararo 1963; Lazarsfeld \& Henry, 1966; Rapoport, 1957). Mathematical sociology, being the precursor of social network analysis (Wasserman \& Faust, 1994), has brought to a slow but steady increase of works adopting systematically a social network analytical approach to networks in the relevant domain. An interesting cue that tourism and hospitality scholars are increasingly relying at least on elementary metrics (such as centrality, density), is that also a number of qualitative studies increasingly report basic metrics derived from formalized SNA (e.g. Czernek, 2017). While in 
some cases this seems related to the need of legitimizing 'with numbers' findings that mainly stem from open-ended or semi-structured interviews, the reason for using those metrics is less superficial and more related to a thorough and clear presentation of the structural features of the networks under scrutiny.

Secondly, we have detected a marginal yet slowly expanding share of mix-methods and multi-method studies (e.g., Czernek-Marszałek, 2019). In some cases, the adoption of mixed methods is explicitly justified on the grounds of enriching a quantitative approach. For instance, Czernek-Marszałek (2019) explicitly adopts a mixed-method approach that resembles, even if not clearly stated by the author, an Explanatory Sequential Design consisting of a first quantitative phase and a second qualitative phase. Indeed, the researcher first began with a quantitative approach whereby, after identifying the relevant actors in the Polish tourism area of Wisła, measures of centrality (including centrality degree, closeness or betweenness) were generated. The quantitative analysis allowed identifying the least and most engaged cooperators in the area (namely central and peripheral actors). In the second, qualitative, stage 48 members of the Wisła Tourism Organization were interviewed (with open-ended and semistructured interviews) and parts of the quotes were deployed to make sense of the 'why' of the business relationships. This allowed the researcher to recognize that "structural positions of interviewees in a cooperation network, identified in quantitative network analysis, can show only a partial picture of an actor's cooperation engagement. Network visualization, possible thanks to quantitative SNA, presents only a snapshot of a network, and without qualitative research it is not enough to fully explain actors' engagement in a cooperation network" (Czernek-Marszałek, 2019: 47). Moreover, the author adds: "Without these opinions, the analysis may not only have been superficial, but also inaccurate. For example, actors not engaged in cooperation could have been perceived as not interested in cooperating" (CzernekMarszałek, 2019: 47). Overall, the Explanatory Sequential Design adopted in this article helped to first get the wide picture of the network of cooperative relationship (quantitative stage) and afterwards to look in depth the qualitative features of the analyzed relationships (qualitative stage).

Third, given the time and resource consuming nature of mixed methods, it appears that several researchers have managed to build a research agenda allowing them to generate multiple outputs (see Czernek-Marszałek, 2018, 2019) basically on the same network. This is a particularly fortunate case as it allows longitudinal approaches to be adopted, that could lead also to Convergent parallel mixed methods designs or even to Explanatory Sequential Design (when the qualitative data collection and analysis is undertaken after the quantitative analysis). 
For instance, the two papers analyzed (Czernek-Marszałek, 2018, 2019) clearly leverage on the same qualitative research and data (open and semi-structured interviews conducted with 48 members of the Wisła Tourism Organzation from July 2013 to December 2014). Certainly, in such cases the issue of presenting the findings for academic outlets might push the researcher to present her research sequenced in ways that do not necessarily correspond with the original research design as some elements of the research might be emergent while other could be (partially) pre-determined.

Fourth, not many purely qualitative researchers have studied large networks where the relevance of every tie needs to be measured. This is certainly one of the cases when resorting to simple metrics would signal comprehensiveness of the methodological approach at the expense of depth in the analysis. As by definition mixed methods include also qualitative methods, we might therefore argue that quantitative methods within mixed methods have so far been used rather to legitimize with "objective metrics" the qualitative analysis of relatively small networks. Interestingly, the development and consolidation of digital technologies has triggered a proliferation of social networking sites (such as Facebook), online travel review sites (such as TripAdvisor) as well as online sharing platforms (such as Airbnb) that allow their users to interact with each other and with companies and brands and create and co-create electronic Word-of-Mouth (eWOM) as well as transactional opportunities. In particular, the role of eWOM has received considerable and increasing attention in tourism and hospitality literature (e.g., Baka, 2016; Cantallops \& Salvi, 2014; Mariani and Borghi, 2018; Mariani and Predvoditeleva, 2019; Yang et al., 2018). E-WOM literature has focused on online review generating factors on the one hand (e.g., Kim et al., 2009) and the impact of the online reviews on companies (Yang et al., 2018) and consumers (e.g., Mariani et al., 2019; Sparks \& Browning, 2011). However, to our knowledge almost no attempts have been made to adopt a truly mixed-method approach to explore first the perceptions of online users when reading online reviews or other social media content (Mariani et al., 2016; Mariani, Ek Styven and Ayeh, 2019) through a kind of netnographic approach to generate a conceptual model of online users behaviour. The model could be tested in a second stage through quantitative methods such as surveys or experiments or even digital analytics (Mariani, 2019).

Fifth, there are very problematic cases whereby the use of quantitative methods vs. qualitative methods to study the very same network might generate significantly different results. As this type of cases typically do not get published, we illustrate this situation by leveraging on an example built re-analysing the data from an unpublished master thesis (Milo, 2015) and using different techniques. The object of study of the thesis was the Italian city of 
Cremona, located on the left bank of the Po River, and renowned for its musical history and traditions. Cremona is the city where the most famous luthiers, such as Amati, Guarneri, Stradivari used to live and work (Cattani et al., 2013). The city offers a number of monuments and testimonials of rich late medieval and Renaissance periods, together with a well-established culinary tradition. The thesis analysed several aspects of the tourism activities in Cremona and studied the structural characteristics of the destination.

Let us consider a first issue. Usually, when analysing a tourism destination, we look first at its main stakeholders, typically identified as those economic and social actors managing and offering tourism products and services (including hospitality services, attractions, etc.). It is common practice in such cases to focus on a number of different industrial and professional associations. In other terms, it is possible to qualitatively sketch the structure of the network as a parsimonious number of 'groups' each formed by a set of homogeneous elements. The question is: is this picture a reliable representation of the networked destination? To address this question, we could resort to quantitative algorithms able to cluster the network based on the similarities in the connectivity between the different actors. The algorithm used is the one developed by Blondel et al. (2008), considered to be one of the most efficient and effective. The results are graphically presented in figure 2, where the clusters uncovered are marked by dotted circles. In these clusters, the actors are coloured according to their type of business (for the sake of simplicity, the following economic actors and businesses were considered: hotels, travel agencies, small accommodation businesses, restaurants, associations and other services). As clear from the graphical representation, no cluster looks like a homogeneous one (in terms of business type). This means that a pure qualitative approach fails to recognise the real structural features of the destination, posing a serious issue to the scholar and to those in charge of the destination governance and management (see also Baggio, 2011). 


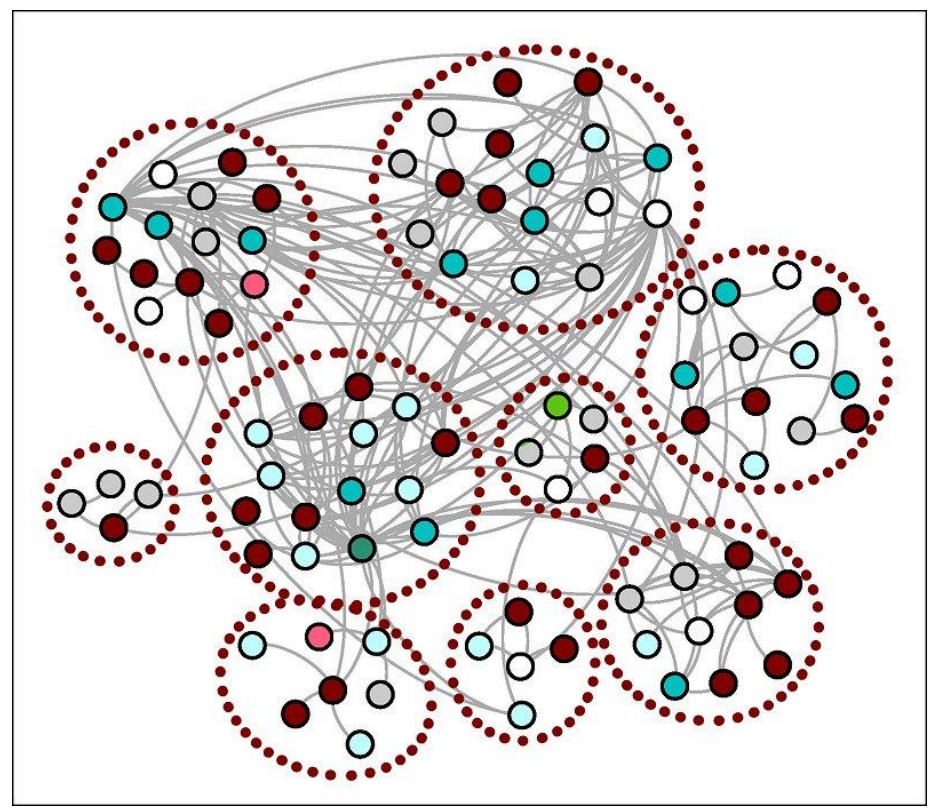

Fig. 2 The clusters identified quantitatively. Nodes are coloured based on their business type (colour online, Source: Authors' elaboration)

A second issue concerns the characteristics of the individual actors in the system. In the same work (Milo, 2015) and looking at the same destination, a qualitative survey was conducted by using a handful of open-ended interviews, aimed at identifying the most relevant actors. The same task can be accomplished by using a set of nodal metrics that can rank the nodes in terms of their connectivity characteristics (degree, closeness, efficiency in transferring information, capability to connect different areas etc.). An 'importance' index can be calculated as the geometric mean of the normalised quantities. Figure 3 illustrates the results graphically: the nodes' sizes are proportional to the calculated importance, and their colour reflects the perceived relevance (converted to an ordinal, the darker the most relevant).

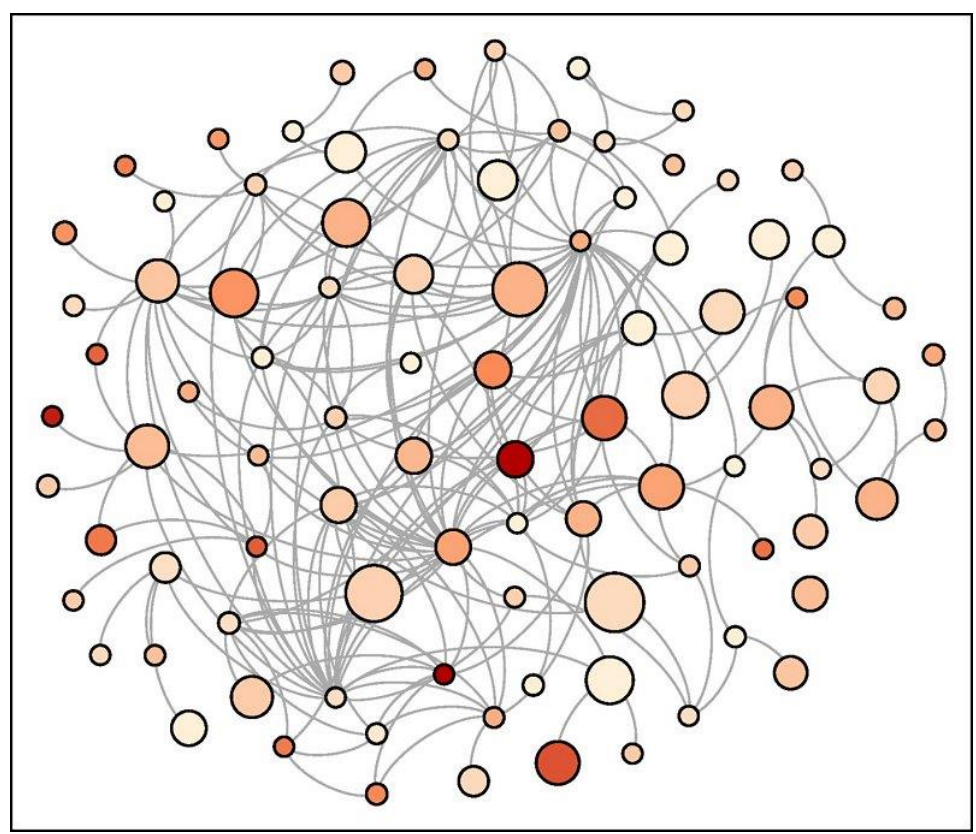


Fig 3 - The Cremona network. The size of nodes indicates the network 'importance', while the colour shows the perceived qualitative relevance (darker = higher, colour online, Source:

Authors' elaboration)

Overall, also in this case, the qualitative and quantitative reconstruction and assessment of the network do not match with each other. Obviously, this does not mean that either one is 'wrong'. It simply suggests that, depending on how we evaluate the characteristics we are interested in, we might come up with different outcomes. Understandably, a suitable combination of the two assessments and methods, namely a mixed method, would be able to provide a more nuanced appreciation of the network's features.

Sixth, while adopting mixed methods could help overcome the issue of getting divergent outcomes when studying the very same network (e.g., Milo, 2015), it is not per se a guarantee that the knowledge of the phenomenon would be enhanced. Based on the studies reviewed and a long past experience working with networks, we believe that the research question related to the network should drive the most suitable research design. Indeed, while quantitative methods are able to tackle causal relationships addressing questions such as the impact of cooperation and friendships among hotel managers on hotels' performance (e.g., Ingram and Roberts, 2000), qualitative methods can help to understand the 'how' of cooperative relationships between hospitality managers. As such, we propose a simple yet helpful contingency framework for tourism researchers that study networks when facing the choice of multiple mixed methods:

- If the first and main research question - in logical and chronological terms - relates mainly to a causal relationship between variables of the social network or variables of the networks and other variables (e.g., performance data of companies in the network), Explanatory sequential methods would be the most suitable. The advantage of such a sequential design is that it allows conducting the research sequentially, one stage at a time (Hollstein \& Dominguez, 2014). However, the main drawback is that it limits the capability to undertake adjustments at later stages and, as the steps are conducted consecutively, they tend to be more time demanding and cost intensive if compared to parallel designs;

- If the first and main research question - in logical and chronological terms - relates mainly to the explanation of the 'how' of the formation and nature of social network relationships, Exploratory sequential methods would be the most suitable. Also in this case advantages and drawbacks are similar to those described in the previous 
point (research conducted at different stages vs. adjustments and costs) (Bernardi et al., 2014);

- If the research embeds main research questions that have both a causal nature and simultaneously require - in logical and chronological terms - to go in depth about the 'how' of the nature of the relationship at the very outset of the research, then Convergent parallel methods might be fruitfully used (Creswell, 2003, 2014). In this case, the main advantages are that adjustments can be carried out and that time and cost can be controlled. However, there are disadvantages related to the i) inability to conduct the research one stage at a time; ii) the need to have different methodological expertise as the same phenomenon is studied by applying two different methods (quantitative and qualitative) simultaneously and this might require a research team with diverse methodological skills that needs to be coordinated.

The aforementioned framework reflects a contingency approach whereby mixed methods are applied differently based on the nature of the research questions. While mixed methods generally display the advantages of both quantitative and qualitative methods, they also display limitations as they need more time, financial resources, coordination, and especially an in-depth methodological knowledge (Creswell 2014).

When we compare different mixed methods, the adoption of an approach over an alternative one will be contingent upon the advantages and disadvantages associated to them. Therefore, no mixed-method approach is superior by construction, but the choice of a specific one will be the outcome of a balancing exercise between the focal research questions, the cost and time intensity, and the need to make adjustments over time by setting up consecutive stages.

Certainly, epistemological stances might play a role as well, and we should add that researchers embracing a postpositivist worldview might find it easier to adopt explanatory sequential methods while researchers embracing a constructivist worldview might find it easier to adopt exploratory sequential methods. In other terms, postpositivists are used to deterministic attitudes and empirical measurement, leading them to focus on the measurable aspects of a social network and the identification of structural properties (see Baggio, 2011), possibly conducive to theory verification. Therefore, they might be prone to first approach the network under analysis (e.g, a tourism destination) by measuring its structural features and only in a subsequent stage they might be willing to dig in depth about their quantitative findings by exploring a few unexpected results by means of a qualitative approach (for instance by 
interviewing major tourism destination 'brokers' or 'boundary spanners'). We envision that the second stage of their research might be carried out in conjunction with scholars more versed in qualitative techniques unless the postpositivist researcher decided to invest time in conducting interviews. The decision to collaborate with a qualitative researcher might or might not generate frictions, based on the flexibility of the researchers to integrate different worldviews.

On the other hand constructivists are used to historical construction or re-construction with the main aim of understanding social dynamics through the production and collection of meaning (see e.g. Beritelli et al., 2015) with the major aim of generating theory or a conceptual framework. Consequently, they might be prone to first approach the social network under analysis (e.g, a tourism destination) by understanding the way individuals make sense of the network by means of open-ended and semi-structured interviews (embedded in case studies or ethnographic research) and once they come up with a conceptual model (for instance using the Gioia methodology, see Gioia et al., 2013), in a subsequent stage they might be willing to test causal relationship among the variables/constructs of the conceptual model. We envision that the second stage of their research might be carried out in conjunction with scholars more versed in quantitative techniques unless the costructivist researcher decided to invest time in learning and using quantitative techniques (e.g., regression analyses, etc.).

Overall, and in light of the potential discrepancy of the findings stemming from purely quantitative methods or purely qualitative methods, we encourage more mixed methods in the study of tourism and hospitality networks. Accordingly, we hope that mixed-method studies, that represent still a minority of the literature dealing with social networks (e.g., CzernekMarszałek, 2018, 2019), might become more popular for the new generations of tourism and hospitality researchers. Accordingly, we urge scholars examining tourism networks to effectively deploy and triangulate qualitative and quantitative methods to unleash the power of mixed methods (Creswell, 2003, 2014; Creswell and Plano Clark, 2007) and gain a richer and more accurate understanding of the tourism and hospitality networks they examine.

\section{Conclusion, implications and limitations}

The analysis conducted provides a number of methodological implications. First, neither a qualitative nor a quantitative analysis of networked tourism and hospitality systems are able, separately, to provide a meaningful outcome as qualitative methods are more suitable to address 'how' exploratory questions while quantitative methods are more appropriate to address causal relationships. 
Second, works adopting mixed methods are a minority out of the overall body of tourism and hospitality network literature. Accordingly, we encourage the current and upcoming generations of scholars to increasingly embrace mixed methods in their studies, as generally mixed methods (for instance fsQCA) are becoming increasingly relevant in the wider tourism and hospitality literature (e.g., Lee et al., 2017; Li et al., 2017; Olya and Alipour, 2015; Olya et al., 2018). Consistently, scholars willing to study tourism and hospitality networks by means of a mixed-method approaches are encouraged to establish research teams with a diversified set of methodological skills, since it is highly unlikely and unrealistic that a single researcher might master all the techniques needed to carry out a solid mixed-method research. As such, we envision that the coordination of the team should be in the hands of a scholar already mastering at least a few quantitative and qualitative methods or even better two scholars, one of them versed in qualitative and the other in quantitative methods.

Third and related to the previous point, the choice of the most suitable type of mixed methods, whether Convergent parallel, Explanatory sequential, Exploratory sequential, or a combination of the first three (Creswell, 2003, 2014) is contingent upon different relevant factors: the type and nature of research questions to be addressed, the epistemological stance embraced by the researchers, the cost and time intensity of the approach, the need to make modification and adjustments over time to the research design.

Fourth, while it is certainly important to deploy mixed methods to gain a rounded picture of networks in tourism and hospitality, network science scholars should be cautious when the mere use of a few consolidated social network analysis metrics is provided simply to give a flavor of objectivity to purely qualitative research designs.

Fifth, this study proposes a simple yet helpful contingency framework for tourism researchers analysing social networks when facing the choice of multiple mixed methods. If the first and main research question - in logical and chronological terms - relates mainly to a causal relationship between variables of the network or variables of the networks and other variables (e.g., performance data of companies in the network), then Explanatory sequential methods would be the most suitable. These methods could be particularly useful to study relationships for which some empirical evidence is already available.

For instance, the effect of sharing economy platforms on incumbent hospitality firms has been addressed through quantitative methods (Zervas et al., 2017) but not triangulated with in depth qualitative interviews capturing the perceptions of incumbents' managers, and sharing economy hosts and guests in relation to the advantages and disadvantages of substituting a traditional hotel service with a less traditional P-2-P accommodation service (Mariani and 
Borghi, 2019). A second possible application might be the study of the impact of electronic Word-of-Mouth from multiple channels on tourism firm financial performance: while some features of online reviews such as valence, volume, and variance have been found to affect hospitality performance (Yang et al., 2018) in quantitative designs, it is not clear to what extent improvements in performance are related to e-reputation and network effects or rather to other factors that are not necessarily controlled for (e.g., local cooperation with destination marketing organizations, efforts of policy makers to make both the destination and hotel firms accessible, etc.) but could be better explained by relying on semi-structured interviews with hotel managers, tourism stakeholders and policy makers.

If the first and main research question - in logical and chronological terms - relates mainly to the explanation of the 'how' of the formation and nature of social network relationships, then Exploratory sequential methods would be the most suitable.

For instance, when comparing the competitiveness of destinations typically tourism researchers invoke a series of factors (Ritchie and Crouch, 2003) such as supporting factors (i.e., infrastructure, accessibility, facilitating resources, hospitality, enterprise, political will), core resources and attractors (i.e., physiography and climate, culture and history, mix of activities, special events, entertainment, superstructure, market ties), destination management, destination policy, planning and development, qualifying and amplifying determinants. However, it is never clear how and if the social factors interplay with other determinants (Mazanec et al., 2007) and if so, how they ultimately would affect the destination competitiveness. As such a first stage encompassing qualitative methods applied to interviews conducted with destination stakeholders in two or three destination, might be followed by a quantitative stage wherein factors are embedded into a model specification and an overall score of competitiveness (or destination competitiveness index) is derived.

If the research embeds questions that have both a causal nature and need to go in depth about the nature of the relationship, then a Convergent parallel method or a combination of the Explanatory sequential, Exploratory sequential and Convergent parallel might be fruitfully used (Creswell, 2003, 2014; Hollstein \& Dominguez, 2014).

This study displays a few limitations. First, it is based on academic articles and research published before 2019. Therefore, publications that appeared starting from January 2019 are not covered. Future research might collect further studies to update the findings of this work. Second, the research outputs were extracted from the database Scopus that indexes the vast majority of high-quality academic journals. However, this does not allow a coverage of the entire population of academic works produced so far. Given that this work has an exploratory 
nature we trust that these preliminary findings are sufficiently robust and might be further validated by considering a larger subset of articles (e.g. those indexed by Google Scholar). Third, more attention should be paid to the complex interplay between research questions, epistemological stances of the researchers and their choice of the specific (mixed) methods when analysing networks in the tourism and hospitality domain. 


\section{REFERENCES}

Baggio, R. (2007), “The Web Graph of a Tourism System”, Physica A, Vol. 379, pp. 727734.

Baggio R., Scaglione M. (2018), "Strategic visitor flows and destination management organization", Information Technology and Tourism, Vol. 18, pp. 29-42.

Baggio, R. (2011), "Collaboration and cooperation in a tourism destination: a network science approach", Current Issues in Tourism, Vol. 14, pp. 183-189.

Baggio, R. (2017), "Network science and tourism - the state of the art", Tourism Review, Vol. 72, pp. 120-131.

Baggio, R., \& Cooper, C. (2010), "Knowledge transfer in a tourism destination: The effects of a network structure", Service Industries Journal, Vol. 30, pp. 1757-1771.

Baggio, R., Scott, N., \& Cooper, C. (2010), "Network science - a review focused on tourism", Annals of Tourism Research, Vol. 37, pp. 802-827.

Baka, V. (2016). The becoming of user-generated reviews: Looking at the past to understand the future of managing reputation in the travel sector. Tourism Management, Vol. 53, pp. 148-162.

Barabási, A. L. (2016). Network science. Cambridge University Press, Cambridge, UK.

Bellotti, E. (2014). Qualitative Networks: Mixed Methods in Sociological Research. Routledge, London.

Beritelli, P., Reinhold, S., Laesser, C., \& Bieger, T. (2015). The St. Gallen model for destination management. St. Gallen, CH: IMP-HSG.

Bernardi, L., Keim, S. and \& Klärner, A. (2014). Social Networks, Social Influence, and Fertility in Germany: Challenges and Benefits of Applying a Parallel Mixed Methods Design. In B. Hollstein \& S. Dominguez (2014). Mixed Methods Social Networks Research: Design and Applications. Cambridge University Press, Cambridge and New York, pp. 121-152.

Björk, P., \& Virtanen, H. (2005), "What tourism project managers need to know about cooperation facilitators", Scandinavian Journal of Hospitality and Tourism, Vol. 5, pp. 212-230.

Blondel, V. D., Guillaume, J. L., Lambiotte, R., \& Lefebvre, E. (2008), "Fast unfolding of communities in large networks", Journal of Statistical Mechanics, Vol. 2008, art. P10008.

Bramwell, B., \& Sharman, A. (1999), “Collaboration in local tourism policymaking”, Annals of Tourism Research, Vol. 26, pp. 392-414.

Cantallops, A. S., \& Salvi, F. (2014), "New consumer behavior: A review of research on eWOM and hotels". International Journal of Hospitality Management, Vol. 36, pp. 41-51.

Casanueva, C., Gallego, Á., \& García-Sánchez, M. R. (2016), "Social network analysis in tourism. Current Issues in Tourism, Vol. 19, pp. 1190-1209.

Cattani, G., Dunbar, R. L., \& Shapira, Z. (2013), "Value creation and knowledge loss: The case of Cremonese stringed instruments", Organization Science, Vol. 24, pp. 813-830.

Cherryholmes, C. H. (1992), "Notes on pragmatism and scientific realism", Educational Researcher, Vol. 14, pp. 13-17.

Christopoulos, D., \& Aubke, F. (2014), "Data Collection for Social Network Analysis in Tourism Research", in M. McLeod \& R. Vaughan (Eds.), Knowledge networks and tourism.: Routledge, New York, pp. 126-142.

Cohen, E., \& Cohen, S. A. (2012), "Current sociological theories and issues in tourism", Annals of Tourism Research, Vol. 39, pp. 2177-2202.

Coleman, J.S. (1964), An Introduction to Mathematical Sociology. Free Press, New York. 
Creswell, J. W., and Plano Clark, V. L. (2007), Mixed methods research, Sage, London. Creswell, J. W. (2014). Research Design: Qualitative, Quantitative and Mixed Method Approaches. Fourth Edition, Sage Publications, Thousand Oaks, CA.

Crotty, M. (1998), The Foundations of Social Research: Meaning and Perspective in the Research Process, Sage, London.

Czakon, W., Klimas, P. \& Mariani, M.M. (2019), "Behavioral antecedents of coopetition: A synthesis and measurement scale", Long Range Planning, doi: 10.1016/j.lrp.2019.03.001

Czernek, K. (2017), "Tourism features as determinants of knowledge transfer in the process of tourist cooperation”, Current Issues in Tourism, Vol. 20, pp. 204-220.

Czernek-Marszałek, K. (2018), "Cooperation evaluation with the use of network analysis", Annals of Tourism Research, Vol. 72, pp. 126-139.

da Fontoura Costa, L., Rodrigues, A., Travieso, G., \& Villas Boas, P. R. (2007), "Characterization of complex networks: A survey of measurements", Advances in Physics, Vol. 56, pp. 167-242.

Dredge, D. (2005), "Networks and Innovation in Lake Macquarie", in D. Carson \& J. Macbeth (Eds.), Regional Tourism Cases: Innovation in regional tourism, STCRC, Gold Coast, pp. 61-68.

Dredge, D. (2006), "Policy networks and the local organisation of tourism", Tourism Management, Vil. 27, pp. 269-280.

Durkheim, E. (1982), The rules of sociological method, The Free Press, New York (English translation with introduction by Steven Lukes).

Éber F.Z., Baggio R., Fuchs M. (2018), "Hyperlink network analysis of a multi destination region: the case of Halland, South Sweden", Information Technology and Tourism, Vol. 20, pp. 181-188.

Edwards D., Cheng M., Wong I.A., Zhang J., Wu Q. (2017), “Ambassadors of knowledge sharing: Co-produced travel information through tourist-local social media exchange", International Journal of Contemporary Hospitality Management, Vol. 29, pp. 690-708.

Eisenhardt KM and Graebner ME (2007), "Theory building from cases: Opportunities and challenges", The Academy of Management Journal, Vol. 50, pp. 25-32.

Fararo, T.J. (1973), Mathematical Sociology, Wiley, New York.

Freeman, L.C. (2004). The Development of Social Network Analysis, Empirical Press, Vancouver.

Gadamer, H-G. (1960), Wahrheit und Methode (German Edition), Degruyter, Berlin.

Gadamer, H-G. (1975), Truth and Method (English Edition), Sheed and Ward Lmt and the Continuum Publishing Group, London.

Ghahramani L., Khalilzadeh J., Kc B. (2018), “Tour guides' communication ecosystems: an inferential social network analysis approach", Information Technology and Tourism, Vol. 20, pp. 103-130.

Gioia, D. A., Corley, K. G., \& Hamilton, A. L. (2013), "Seeking qualitative rigor in inductive research: Notes on the Gioia methodology", Organizational Research Methods, Vol. 16, pp. 15-31.

Heidari, A., Yazdani, H. R., Saghafi, F., \& Jalilvand, M. R. (2018), “A systematic mapping study on tourism business networks", European Business Review, Vol. 30, pp. 676706.

Hollstein, B. Dominguez, S. (2014). Mixed Methods Social Networks Research: Design and Applications, Cambridge University Press, Cambridge and New York.

Hughes, J. (1997) The Philosophy of Social Research, 3rd Ed., Longman, London. 
Ingram, P., \& Roberts, P. W. (2000), "Friendships among competitors in the Sydney Hotel Industry", American Journal of Sociology, Vol. 106, pp. 387-423.

Kimbu, A.N. \& Ngoasong, M. Z. (2013), "Centralised decentralisationof tourism development: a network perspective", Annals of Tourism Research, Vol. 40, pp. 235259.

Kuhn, T. S. (1962), The Structure of Scientific Revolutions, University of Chicago Press, Chicago.

Kylänen, M., \& Mariani, M. M. (2014), "Cooperative and coopetitive practices: Cases from the tourism industry", in M. M. Mariani, R. Baggio, D. Buhalis, \& C. Longhi (Eds.), Tourism management, marketing, and development: Volume I: The Importance of Networks and ICTs, Palgrave, New York, pp. 149-178, doi: 10.1057/9781137354358_9.

Law, R., Sun, S., Fong, D. K. C., Fong, L. H. N., \& Fu, H. (2016). "A systematic review of China's outbound tourism research", International Journal of Contemporary Hospitality Management, Vol. 28, pp. 2654-2674.

Lazarsfeld, P.F, Henry, N.W. (1966), Readings in Mathematical Social Science. MIT Press, Boston.

Lee, Y-H., Hsiao, C., and Chen, Y-C. (2017), "Linking positive psychological capital with customer value co-creation", International Journal of Contemporary Hospitality Management, Vol. 29, pp.1235-1255.

Li, H., Xu, Y-H., and Yu, L. (2017), "Predicting hospitality firm failure: mixed sample modelling", International Journal of Contemporary Hospitality Management, Vol. 29, 7, pp.1770-1792.

Luthe T., Wyss R., Schuckert M. (2012), "Network governance and regional resilience to climate change: Empirical evidence from mountain tourism communities in the Swiss Gotthard region", Regional Environmental Change, Vol. 12, pp. 839-854.

March, R. \& Wilkinson, I. (2009), "Conceptual tools for evaluating tourism partnerships", Tourism Management, Vol. 30, pp. 455-462.

Mariani, M.M., Baggio, R., Buhalis, D., Longhi, C. (2014), Tourism Management, Marketing and Development: Volume I: the Importance of Networks and ICTs, Palgrave, New York, doi: 10.1057/9781137354358.

Mariani, M.M, Buhalis, D. Longhi C., Vitouladiti, O. (2014), "Managing change in tourism destinations: Key issues and current trends", Journal of Destination Marketing \& Management, 2, 269-272.

Mariani, M.M, Di Felice, M., Mura, M. (2016), "Facebook as a Destination Marketing Tool: Evidence from Italian regional Destination Management Organizations", Tourism Management, Vol. 54, pp. 321-343.

Mariani, M.M., 2016, "Coordination in inter-network co-opetitition: Evidence from the tourism sector", Industrial Marketing Management, Vol. 53, pp. 103-123.

Mariani, M.M. and Giorgio, L. (2017), "The "Pink Night" festival revisited: Meta-events and the role of destination partnerships in staging event tourism", Annals of Tourism Research, Vol. 62, pp. 89-109.

Mariani, M.M, Borghi, M. (2018), "Effects of the Booking.com rating system: Bringing hotel class into the picture", Tourism Management, 66, 47-52

Mariani, M.M., Baggio, R., Fuchs, M., Höpken, W. (2018), "Business Intelligence and Big Data in Hospitality and Tourism: A Systematic Literature Review", International Journal of Contemporary Hospitality Management, Vol. 30, pp. 35143554.

Mariani, M.M. (2019), "Big data and analytics in tourism and hospitality: a perspective article”, Tourism Review, https://doi.org/10.1108/TR-06-2019-0259. 
Mariani, M.M., Borghi, M. (2019), "Industry 4.0: A Bibliometric Review of its Managerial Intellectual Structure and Potential Evolution into the Service Industries", Technological Forecasting and Social Change, https://doi.org/10.1016/j.techfore.2019.119752.

Mariani, M.M., Borghi, M., Gretzel, U. (2019), "Online reviews: Differences by submission device", Tourism Management, 70, 295-298.

Mariani, M., Predvoditeleva, M. (2019), "How do online reviewers' cultural traits and perceived experience influence hotel online ratings? An empirical analysis of the Muscovite hotel sector", International Journal of Contemporary Hospitality Management, Vol. 31 No. 12, pp. 4543-4573. https://doi.org/10.1108/IJCHM-112018-0927

Mariani, M.M., Ek Styven, M., Ayeh, J. (2019). "Facebook for travel decision-making: An international study of antecedents", International Journal of Contemporary Hospitality Management, Vol. 31 No. 2, pp. 1021-1044.

Mazanec, J. A., Wöber, K., \& Zins, A. H. (2007). "Tourism destination competitiveness: from definition to explanation?. Journal of Travel Research, Vol. 46 No. 1, pp. 86-95

Merinero-Rodríguez, R., \& Pulido-Fernández, J. I. (2016), “Analysing relationships in tourism: A review", Tourism Management, Vol. 54, pp. 122-135.

Milo, P. (2015), Destination Management e il Capitale Sociale: il caso della provincia di Cremona. Unpublished MSc Thesis, Libera Università di Lingue e Comunicazione IULM, Milan.

Mulkay, M. J., Gilbert, G. N., \& Woolgar, S. (1975), "Problem Areas and Research Networks in Science", Sociology, Vol. 9, pp. 187-203.

Novelli, M., Schmitz, B., \& Spencer, T. (2006), "Networks, clusters and innovation in tourism: A UK experience", Tourism Management, Vol. 27 No. 6, 1141-1152.

Olya, H. G., Gazi, Z., Aksal, F., and Altinay, M. (2018), "Behavioral intentions of disabled tourists for the use of peer-to-peer accommodations: An application of fsQCA", International Journal of Contemporary Hospitality Management, Vol. 30 No.1, pp. 436-454.

Olya, H., and Alipour, H., (2015), "Modelling Tourism Climate Indices through Fuzzy Logic", Climate Research, Vol. 66, pp. 49-63.

Phillips, D. C., \& Burbules, N. C. (2000), Postpositivism and educational research, Rowman \& Littlefield, Lanham, MD.

Popper, K. (1959), The Logic of Scientific Discovery, Hutchinson, London.

Racherla P. \& Hu C. (2010), "A social network perspective of tourism research collaborations", Annals of Tourism Research, Vol. 37, pp. 1012-1034.

Raisi H., Baggio R., Barratt-Pugh L., Willson G (2018), "Hyperlink Network Analysis of a Tourism Destination", Journal of Travel Research, Vol. 57, pp. 671-686.

Rapoport, A. (1957). "Contributions to the Theory of Random and Biased Nets." Bulletin of Mathematical Biophysics, Vol. 19, pp. 257-277.

Rossman, G. B., \& Wilson, B. L. (1985), "Numbers and Words: Combining Quantitative and Qualitative Methods in a Single Large-Scale Evaluation Study", Evaluation Review, Vol. 9, pp. 627-643.

Sainaghi R., Phillips P., Baggio R., Mauri A. (2019), "Hotel performance: Rigor and relevant research topics", International Journal of Hospitality Management, Vol. 78, pp. 1326.

Scott, N., Baggio, R. and Cooper, C. (2008), Network Analysis and Tourism: From Theory to Practice, Channel View, Clevedon, UK. 
Sedita, S.R. (2008), "Interpersonal and Inter-organizational Networks in the Performing Arts: The Case of Project-Based Organizations in the Live Music Industry", Industry and Innovation, Vol. 15, pp. 493-511

Smith, J. K. (1983), "Quantitative versus interpretive: The problem of conducting social inquiry", in E. R. House (Ed.), Philosophy of evaluation. New Directions for program evaluation, JosseyBass, San Francisco, CA, pp. 75-82.

Snehota, I., \& Hakansson, H. (1995), Developing relationships in business networks, Routledge, London

Teddlie, C., and Tashakkori, A. (2009), Foundations of Mixed Methods Research, Sage, London.

Timur S., Getz D. (2008), “A network perspective on managing stakeholders for sustainable urban tourism", International Journal of Contemporary Hospitality Management, Vol. 20, pp. 445-461.

van der Zee E., Bertocchi D. (2018), "Finding patterns in urban tourist behaviour: a social network analysis approach based on TripAdvisor reviews", Information Technology and Tourism, Vol. 20, pp. 153-180.

van der Zee, E., \& Vanneste, D. (2015), “Tourism networks unravelled; a review of the literature on networks in tourism management studies", Tourism Management Perspectives, Vol. 15, pp. 46-56.

Van Maanen, J. (1979, "The Fact of Fiction in Organizational Ethnography”, Administrative Science Quarterly, Vol. 24, pp. 539-550.

Vieira, E. S. and Gomes, J. A. (2009), "A comparison of Scopus and Web of Science for a typical university", Scientometrics, Vol. 81 No. 2, pp. 587-600.

Wasserman, S. \& Faust, K. (1994). Social network analysis: Methods and applications, Cambridge University Press, Cambridge.

Wells, V.K., Manika, D., Gregory-Smith, D., Taheri, B., and McCowlen, C. (2015), "Heritage tourism, CSR and the role of employee environmental behaviour", Tourism Management, Vol. 48, pp. 399-413.

Yang, Y., Park, S., \& Hu, X. (2018). Electronic word of mouth and hotel performance: a meta-analysis. Tourism Management, Vol. 67, pp. 248-260.

Yin, R. K. (2017), Case study research and applications: Design and methods, Sage publications, Thousand Oaks, CA.

Zervas, G., Proserpio, D., \& Byers, J. W. (2017). The rise of the sharing economy: Estimating the impact of Airbnb on the hotel industry. Journal of Marketing Research, Vol. 54, pp. 687-705. 
Appendix - List of articles considered

\begin{tabular}{|c|c|c|}
\hline $\begin{array}{l}\text { Paper } \\
10\end{array}$ & Article Title & Source title \\
\hline 1 Pan B, Maclaurin T, Crotts I.C. & 2007 Travel blogs and the implications for destination marketing & Journal of Travel Research \\
\hline 2 Scott N, Cooper C, Baggjo R. & 2008 Destination Networks. Four Australian Cases & Annals of Tourism Ressearch \\
\hline 3 Tribet. & 2010 TRIBES, TERRITORIES AND NETWORKS IN THE TOURISM ACADEMY & Annals of Tourism Research \\
\hline \multicolumn{3}{|l|}{ Kajiklawa Y, Ohno L., Takeda Y., } \\
\hline & 2007 Creating a a cadedemic landscape of sustainability science: An analysis of the citation network & Sustainability science \\
\hline 5 Timur S, Getz D. & 2008 A network perspective on managging stakeholdders for sustainable urban tourism & International J ournal of Contemporary Hospitality Management \\
\hline 6 Baggio R, Scott N., Cooper C. & 2010 Network science. A review focused on tourism & Annals of Tourism Research \\
\hline 7Shih H.Y.Y. & 2006 Network characteristics of drive tourism destinations: An application of network analysis i in tourism & Tourism Management \\
\hline 8 Pfortc. & 2006 Tourism policy in the making. An Australian network study & Annals of Tourism Research \\
\hline 9 Baggio R, Cooper C. & 2010 Knowledge transfer in a tourism destination: The effects of a network structure & Service Industries Lournal \\
\hline 10 Beritellip. & 2011 cooperation among prominent actors in a tourist destination & Annals of Tourism Research \\
\hline 11 Zhong C, Arisona S.M., Huang X, Batty M., Schmitt G. & 2014 Detecting the dynamics of urban structure through spatial network analysis & International Journal of Geographical Information Science \\
\hline 12 O'Brien $D$. & 2006 Event business leveraging The Sydney 2000 Olympic Games & Annals of Tourism Research \\
\hline 13 Racherla P., HuC. & 2010 A social network perspective of tourism research collaborartions & Annals of Tourism Research \\
\hline 14 Arentze $\mathrm{T}$, Timmermans $\mathrm{H}$. & 2008 Social networks, social interactions, and activity travel behavior: A Aframevork for milcrosimulation & Environment and Planning B: Planning and Design \\
\hline 15 Hu C, Racherla P. & 2008 Visual represesentation of knowledge networkis: A social network nnalysis of hospitality research domain & International Journal of Hospitality Management \\
\hline 16 Benckendorff $P$, Zehrer $A$. & 2013 A network analysis of tourism research & Annals of Tourism Research \\
\hline 17 March R., Wilkinson I. & 2009 Conceptual tools for evaluating tourism partherships & Tourism Management \\
\hline \multirow[t]{2}{*}{18 Pechlaner H, Baggio R, Scott N., Cooper C. } & 2010 Improving tourism destination governance: a complexity science approach & Tourism Review \\
\hline & Using social network analysis to explain communication characterisitics of travel-related & \\
\hline 19 Luo Q, Zhong $D$. & 2015 electronic word-of-mouth on social networking sites & Tourism Management \\
\hline 20 Derrible S, Kennedy C. & 2009 Network analysis of world subway ystems using updated graph theory & Transportation Ressearch Record \\
\hline 21 Beckens. & 2013 A review of tourism and climate change as an evolving knowledge domain & Tourism Management Perspettives \\
\hline 22 lius, ZhuX. & 2004 Accessibility Analyst. An integrated GIS tool for accessibility analysis in urban transportation planning & Environment and Planning B: Planning and Design \\
\hline 23 Pechlaner H., Presenza A., Gipollina M. & 2010 Anayysing tourism stakeholders networks & Tourism Review \\
\hline 24 Volgger M., Pechlaner H. & 2014 Requirements for destination management organizations in destination governance: Understanding DMO success & Tourism Management \\
\hline Soh H, lim S, Zhang T., FuX, lee G.K.K., & & \\
\hline 25 Hung T.G.G, D. P., Prakassam S, Wong L. & 2010 Weighted complex network analysis of travel routes on the Singapore public transportation system & Physica A: Statastical Mechanics and its Applications \\
\hline & Power dimensions and influence reputation in tourist destinations: & \\
\hline 26 Bertitlli P, Leesser C. & 2011 Empirical evidence trom a network of actors and stakeholders & Tourism Management \\
\hline 27 Kalandides A, Zenker S, Beckmann S.C. & 2013 My place is not your place - different place brand knowledge by different terget froups & Journal of Place Management and Development \\
\hline & Connetting social networks with ecosystem services for watershed governance: & \\
\hline 28 Rathwell KL., Peterson G.D. & 2012 A social-ecological network perspective hightights the critical role of bridging organizations & Ecology and Society \\
\hline 29 CaoJ., LuXXC., Wang Y, L L Q. & 2013 Accessibility impacts of China's high-speed rail network & Journal of Transport Geography \\
\hline 30 Baggio R. & 2011 Collaboration and cooperation in a tourism destination: A network science approach & Current Issues in Tourism \\
\hline 31 Ye Q, liT, law R. & 2013 A Coauthorship Network Analysis of Tourism and Hospitality Research Collaboration & Journal of Hospitality and Tourism Research \\
\hline 32 Hwang Y.H.,Gretzel U, Fessenmaier D.R. & 2006 Multicty trip patterns. Tourists to the United States & Annals of Tourism Research \\
\hline 33 Nunkoo R, Gursoy D, Ramkissoon H. & 2013 Developments in Hospitality Marketing and Management Social Network Analysis and Research Themes & Journal of Hospitality Marketing and Management \\
\hline & Network governance and regional resilience to climate change: & \\
\hline 34 Luthe T., Wyss R., Schuckert M. & 2012 Empirical evidence from mountain tourism communities in the Swiss Gotthard region & Regiona Environmental Change \\
\hline 35 Kimbu A.N, Ngoasong M.Z. & 2013 Centra lised decentral isation of tourism development: A network Perspective & Annals of Tourism Ressearch \\
\hline 36 LiX, Stepchenkova S. & 2012 Chinese outbound tourists' destination image of Americe: Part I & Journal of Travel Research \\
\hline 37 Zenker S, Egerers F, Farsky M. & 2013 Putting a price tag on cities: Insights into the competitive environment of places & Cities \\
\hline 38 Garcia-Melón M., Gómez-Navarro T, Acuña-Dutra S. & 2012 A combined ANP-delphi approach to evaluate sustainable tourism & Environmental Impact Assessment Review \\
\hline 39 Leung X.Y, Wang F, Wu B, Bai B, Stahura K.A, Xie Z. & 2012 A Social Network Analysis of Overseas Tourist Movement Patterns in Beijng: The Impact of the Olympic Games & International Journal of Tourism Research \\
\hline 40 Del Chiappa G, Baggio R. & 2015 Knowledge transfer in smart tourism destinations: Analyzing the effects of a network structure & Journal of Destination Marketing and Management \\
\hline & Themes and trends in Australian and New Zealand tourism research: & \\
\hline 41 Benckendorff $P$. & 2009 A social network analysis of ctations in two leading journals (1994-2007) & Journal of Hospitality and Tourism Management \\
\hline 42 Ye Q, Song H., LiT. & 2012 Cross-institutional collaboration networks in tourism and hospitality research & Tourism Management Perspettives \\
\hline 43 Van der Zee E, Vanneste $D$. & 2015 Tourism networks unravel led; a review of the itterature on networks in tourism management studies & Tourism Management Perspettives \\
\hline 44 Mackellart. & 2006 Conventions, festivals, and tourism: Exploring the network that binds & Journal of Convention and Event Tourism \\
\hline & The use of network analysis to assess relationships among stakeholders within a tourism destination: & \\
\hline 45 Del Chiappa G, Presenzza A. & 2013 An emprical investigation on costa smeralda-gallura, taly & Tourism Analysis \\
\hline & The potential of management networks in the innovation and compettiveness of rural tourism: & \\
\hline 46 Romeiroa $\mathrm{P}, \mathrm{Cos}$ tab $\mathrm{C}$. & $2010 \mathrm{~A}$ case study on the Valle del Jerte (Spain) & Current Issues in Tourism \\
\hline 47 Lee S.H., Choil.H.Y, Yoo S.H, OhY.G. & 2013 Evaluating spatial centrality for integrated tourism management in rural areas using GIS and network analysis & Tourism Management \\
\hline 48 Standla $C$, BjörkP. & 2013 Tourism experience network: Co-creation of experiences in interactive processes & International Journal of Tourism Research \\
\hline 49 Scott N., Laws E. & 2006 Tourism crises and disasters: Enhancing understanding of system effects & Journal of Travel and Tourism Marketing \\
\hline 50 Prats L, Guia L, Molina F.-X. & 2008 How tourism destinations evolve: The Notion of Tourism Local Innovation System & Tourism and Hospitality Research \\
\hline 51 Bondavalli C, Bodini A, Rossetti G, Allesina S. & 2006 Detecting stress at the vhole-ecosystem level: The cass of a mountain lake (Lake Santo, ttaly) & Ecosystems \\
\hline 52 Sallent 0 , Palau R, Guia J. & 2011 Exploring the Legacy of Sport Events on Sport Tourism Networks & European Sport Management Quarterly \\
\hline 53 Chalkti K., Sggala M. & 2010 Staff turnover in the Greek tourism industry: A comparison between insular and peninsular r regions & International Journal of Contemporary Hospitality Management \\
\hline 54 çakmak E, Isaac R.K. & 2012 What destination marketers can learn from their visitors' blogs: An image analysis of Bethlehem, Palestine & Journal of Destination Marketing and Management \\
\hline 55 Brés J.M, Costa C, Buhalis D. & 2010 Network analysis and wine routes: The case of the Bairrada Wine Route & Service Industries Lournal \\
\hline 56 Lakas V, Costa C.A. & 2010 Explicating inter-organizational linkages of a host community's events netwvork & International J Jurnal of Event and Festival Management \\
\hline 57 Chow-White P.A. & 2006 Race, gender and sex on the net: Semantic networks of selling and stontelling sex tourism & Media, Cuture and Society \\
\hline 58 Scott N, Laws E. & 2010 Advances in service networks research & Service Industries Sournal \\
\hline & The intel lectual structure of research in hospitality management: & \\
\hline 59 Garcia-lillo F, Übeda-Garcia M., Marco-Lajara B. & 2016 Aliterature review using bibliometric methods of the juurnal International Journal of Hospitality Management & International J Jurnal of Hospitality Management \\
\hline 60 Kowald M., Axhausen K.W. & 2012 Focusing on connected personal leisure networks: Selected results from a snowball sample & Environment and Planning A \\
\hline 61 Ying T, XiaO H. & 2012 Knowledge Linkage: A Social Network Anayysis of Tourism Dissertation Subjects & Journal of Hospitality and Tourism Research \\
\hline 62 Baggio R, Del Chiappa G. & 2014 Real and virtual relationships in tourism digital ecosystems & Information Technology and Tourism \\
\hline 63 Mathews V.E. & 2000 Compettion in the internationa hotel industry & International J Jurnal of Contemporary Hospitality Management \\
\hline 64 Maness M., Cirillo C., Dugundji E.R. & 2015 Generalized behavioral framework for choice models of social influence: Behavioral and data concerns in travel behavior & Journal of Transport Geography \\
\hline 65 Huang G.Q, Song H, Zhang X. & $2010 \mathrm{~A}$ comparative analysis of quantity and price compettitions in tourism supply chain networks for package holidays & Service Industries Sournal \\
\hline 66 Wäsche H. & 2015 Intererganizational cooperation in sport tourism: A social network analysis & Sport Management Review \\
\hline 67 Carson D.A, Carson D.B, Hodge H. & 2014 Understanding local innovation systems in peripheral tourism destinations & Tourism Geographies \\
\hline 68 Karisen S., Nordström C.S. & 2009 Festival in the barents region: Explocing festival-stakeholder cooperation & Scandinavian Journal of Hospitality and Tourism \\
\hline 69 Baggio R, Sainaghi R. & 2016 Mapping time series into networks as a tool to assess the complex dynamics of tourism systems & Tourism Management \\
\hline 70 Cassnueva C, Gallego A., Garcia-Sánchez M.R. & 2016 Social network analysis in tourism & Current Issues in Tourism \\
\hline 71 Hede A-M, Stokes R. & 2009 Network analysis of tourism events: An approach to improve marketing pratcices for sustainable tourism & Journal of Travel and Tourism Marketing \\
\hline 72 Asero V, GozzoS., TomaselliV. & 2016 Building Tourism Networks through Tourist Mobility & Journal of Travel Research \\
\hline 73 D'Agata R, Gozzo S, Tomaselli V. & 2013 Network analysis approach to map tourism mobility & Quality and Quantity \\
\hline 74 Brown B, Barkhuus L. & 2007 Liisure and CSCW: Introduction to special edition & Computer Supported Cooperative Work \\
\hline 75 Farsani N.T., Coelho CO.A., Costa C.M.M. & 2014 Anayysis of network activites in geoparks as geotourism destinations & International Journal of Tourism Research \\
\hline 76 Gao S., Chen B, Yang Z.F, Huang G.H. & 2010 Network environ analysis of spatial arrangement for reserves in Wuyishan Nature Reserve, China & Journal of Environmental Informatics \\
\hline 77 Ying T, Norman W.C, Zhou Y. & 2016 Online Networking in the Tourism Industry: A Webometrics and Hyperlink Network Analysis & Journal of Travel Research \\
\hline 78 Edwards D, Cheng M., Wong IA, Z, Zhang L, Wu Q. & 2017 Ambasssadors of Knowledge sharing Co-produced travel information through tourist-10cal social media exchange & International Journal of Contemporary Hospitality Management \\
\hline & An analysis of the utilization of Facebook by local Korean governments & \\
\hline 79 ParkJ.H., Lee C, Yoo C, NamY. & 2016 for tourism development and the network of smart tourism ecosystem & International J Jurnal of Information Management \\
\hline 80 Casanueva C, Gallego T., Castrol, Sancho M. & 2014 Airline alliances: Mobilizing network resources & Tourism Management \\
\hline
\end{tabular}


Appendix - List of articles considered (continued)

\begin{tabular}{|c|c|c|}
\hline $\begin{array}{l}\text { Paper } \\
\text { ID }\end{array}$ & Artide Title & Source title \\
\hline 81 Liu B, Huang S.S., Fu H. & 2017 An application of network analysis on tourist attractions: The cass of Xnj.jang, China & Tourism Managgenent \\
\hline 82 Horner M.W., Zook B., Downs. J.A. & 2012 Where were you? Development of a time-geographic approach for activity destination re-construction & Computers, Environment and Urban Systems \\
\hline 83 Cobbs J.B. & 2011 The dynamics of relationship marketing in international sponsorship networks & Journa of Business and Industria | Marketing \\
\hline 84 Williams N.L, Inversini A, Buhalis D, Ferdinand N. & 2015 Community crosstak: An expoloratory analysis of destination and festival eWOM on Twitter & Journal of Marketing Management \\
\hline $\begin{array}{l}\text { Roy P., Martinez A.J, Miscione G., } \\
85 \text { zuidgeest M.H.P., van Marsseveen M.F.A.M.M. }\end{array}$ & 2012 Using Social Network Anayysis to profile people based on their e-communication and travel balance & Jounal of Transport Geography \\
\hline 86 Stienmetz J.L, Fesenmaier D.R. & 2015 Estimating value in Batimore, Maryland: An attractions network analyjis & Tourism Management \\
\hline 87 Beritelli P., Strobl A., Peters M. & 2013 Interlocking directorships against community dosure: A trade-off for development in tourist destinations & Tourism Review \\
\hline 88 Dela Santa E. & 2013 The Politics of Implementing Philippine Tourism Policy: A Policy Network and Advocazy Coalition Framework Approach & Asia Pacific Journal of Tourism Research \\
\hline 89 Luthe T, Wyss R. & 2016 Resilience to climate change in a cross-scale tourism governance context: A combined quantitative-qualitative network analysis & Ecology and Society \\
\hline 90 Banyai M. & 2012 Travel Blogs: A Reflection of Postitioning Strategies? & Journal of Hospitality Marketing and Management \\
\hline 91 Watts M. & 2009 Collaborative implementation network structures: Cutural tourism implementation in an english seaside context & Systemic Pratcice and Action Research \\
\hline 92 de Montis A, Caschilis, Chessa A. & 2011 Spatial complex network analysis and accessibility indicators: The csese of Municipal Commuting in Sardinia, Italy & European Journal of Transport and Infrastructure Research \\
\hline 93 Aubke F, Wober K, Scott N, Baggio R. & 2014 Knowledge sharing in revenue managemenent teams: Antecedents and consequences of group cohesion & International Journal of Hospitality Management \\
\hline 94 Hwang D., Stewart W.P. & 2017 Social Capita and Collective Action in Rural Tourism & Journal of Travel Research \\
\hline 95 Tran M.T.T., Jeeva A.S., PourabedinZ. & 2016 Social network analy ys in tourism services distribution channels & Tourism Management Persoectives \\
\hline 96 lockyer T, Ryan C. & 2007 Vistiting friends and relatives-distinguishing between the two groups: The case of Hamilton, New Zealand & Tourism Recreation Research \\
\hline 97 Scott N, Baggo R., Cooper C. & 2011 Network analysis methods for modeling tourism inter-organizational systems & Advances in Culture, Tourism and Hospitality Research \\
\hline 98 Wood $G$ & 2003 Model ling the eccological footprint of geen travel plans using GIS and network analysis: From metaphor to management tool? & Environment and Planning B: Planning and Design \\
\hline 99 Soteriades M.D., Dimoul. & 2011 Special events: A framework for efficient management & Jounal of Hospitality Marketing and Management \\
\hline 100 Bendle LL, Patterson I. & 2010 The centrality of service organizations and their lesisure networks & Service Industries Journal \\
\hline 101 Grama C.N., Baggio R. & 2014 A network analysis of Sibiu County, Romania & Annals of Tourism Research \\
\hline 102 Maciejeuski K., Cumming G.S. & 2015 The relevance of socioeconomic interactions for the ressliennce of protected area networks & Ecosphere \\
\hline 103 Djurhuus S., Sten Hansen H, Aadah I., Glümer C. & 2016 Building a mutimoda network and determining individual accessibility by publictransportation & Environment and Planning B: Planning and Design \\
\hline 104 ParkS., Tussyadiah L.P, Mazznec J.A, Fesenmaier D.R. & 2010 Travel personae of American pleasure travelers: A network analysis & Jounal of Travel and Tourism Marketing \\
\hline 105 Baggio R. & 2014 Complex tourism systems: A visbility graph approach & Kybernetes \\
\hline $106 \mathrm{Kim} \mathrm{D.,} \mathrm{Kim} \mathrm{S.}$ & 2017 The role of mobile technology in tourism: Patents, articles, news, and mobile tour app reviews & Sustainability/Switzerland) \\
\hline 107 Hew.J.J, Leong L-Y., Tan G.W.H.H, Lee V.H.H, Ooi K-B. & 2018 Mobile social tourism shopping. A dual-stage analysis of a muti-mediation model & Tourism Management \\
\hline 108 Beritell P., Buffa F, Martini U. & 2015 The coordinating DMO or coordinators in the DMO? - an alternative perspective with the help of network analysis & Tourism Review \\
\hline 109 Baggio R. & 2017 Network science and tourism - the state of the art & Tourism Review \\
\hline 110 Williams N.L, Inversini A, Ferdinand N., Buhalis D. & 2017 Destination eWOM: A macro and meso network approach? & Annals of Tourism Research \\
\hline 111 Harra S., Fletcher J., Wilkes K. & 2017 An evaluation of power relationships among stakeholders in the tourism industry networks of Agra, India & Current issues in Tourism \\
\hline 112 Sainaghi R, Philips P., Baggo R, Mauri A. & 2018 Cross-citation and authorship analysis of hotel performance studies & International Journal of Hospitality Management \\
\hline 113 Jin $C_{1}$, Cheng J, Xu」. & 2018 Using User-Generated Content to Explore the Temporal Heterogenenity in Tourist Mobility & Journal of Travel Research \\
\hline 114 Khalizzadeh」. & 2018 Demonstration of exponential random graph models in tourism studes: Is tourism a means of global peace or the bottom line? & Annals of Tourism Research \\
\hline 115 Bendle Lل. & 2018 The structures and flows of a large tourist tinerancy network & Current lssues in Tourism \\
\hline 116 Lee Y., Km l. & 2018 Change and stability in shopping tourist destination networks: The case of Seoul in Korea & Jounal of Destination Marketing and Management \\
\hline 117 Hernández J.M., Krilenko A.P., Stepchenkova S. & 2018 Network approach to tourist segmentation via user generated content & Annals of Tourism Research \\
\hline 118 Brandỗo F, Costa C, Buhalis D. & 2018 Tourism innovation networks: Aregional approach & European Juunal of Tourism Research \\
\hline 119 Bonn M.A, cho M, Um H. & 2018 The evoulution of wine research: $A 26$ year historical examination of topics, trends and future direction & International Journal of Contemporary Hospitality Management \\
\hline 120 Kang S, Lee G, Kim J, Park D. & $\begin{array}{l}\text { Identifining the spatial structure of the tourist attraction system in South Korea } \\
2018 \text { using GI and network analysis: An application of anchor-point theory }\end{array}$ & Jounal of Destination Marketing and Managgement \\
\hline 122 Pulido-Fernández z.l., Merinero-Rodriguez R. & 2018 Destinations' reatational dynamic and tourism development & Jounal of Destination Marketing and Managgement \\
\hline 122 Tasci. A.DA., Khallizadeh J, Pizam A., Wang Y. & 2018 Network analysis of the sensory capital of a destination brand & Jounna lof Destination Marketing and Managgement \\
\hline 123 Yang Y. & 2018 Understanding tourist attraction cooperation: An application of netwiork nnalysis to the case of Shanghni, China & Jounal of Destination Marketing and Managgement \\
\hline 124 Raisi H, Baggio R, Barratt:Pughh, Willson G. & 2018 Hyperlink Network Analysis of a Tourism Destination & Journal of Travel Ressarch \\
\hline 125 Güzeller C. 0 , Çel|Ker N. & 2018 Bibliometric analysis of tourism research for the period $2007-2016$ & Advances in Hospitality and Tourism Research \\
\hline 126 Czernek-MarszalekK. & 2018 Cooperation evaluation with the use of network analysis & Annals of Tourism Research \\
\hline 127 Han H, Kim S.S., Otoo F.E. & 2018 Spatial movement pattems among intra-destinations using social network analysis & Asia Pacific Journal of Tourism Research \\
\hline 128 Baggio R, Scaglione M. & 2018 Strategic visitor flows and destination management organization & Information Technology and Tourism \\
\hline 129 LozanoS, Gutiérrez E. & 2018 A complex network analysis of global tourism flows & International Journa of Tourism Research \\
\hline 130 Hoegh-Guldberg O, Eide D, Trengereid V, Hijemdah K.M. & 2018 Dynamics of innovation network journeys: phases and crossroads in seven regional innovation networks & Scandinavian Journal of Hospitality and Tourism \\
\hline 131 Huang $C \cdot W$. & 2018 Assessing the performance of tourism supply chains by using the hyorid network data envelopment analysis model & Tourism Management \\
\hline 132 Provenzano D, Hawelka B, Baggo R. & 2018 The moblilty network of European tourists: a longtudinal study and a comparison with geo-located Twitter data & Tourism Review \\
\hline 133 Guzeller C.O., Celiker N. & 2019 Bibliometrica l nalyysis of Asia Pacific Journa of Tourism Research & Asia Pacific Journal of Tourism Research \\
\hline $134 \mathrm{Kim}$ Y.R., ScottN. & 2018 Network dynamics of tourism development in South Korea & Current Issues in Tourism \\
\hline $\begin{array}{l}\text { David-Negere T, Almedida-Santina A, } \\
135 \text { Hernández J.M., Moreno-Gil S. }\end{array}$ & 2018 Understanding European tourists' use of e-tourism platforms. Analysis of networks & Information Technology and Tourism \\
\hline 136 Éber FL, Baggo R, Fuchs M. & 2018 Hyperlink network analysis of a muti destination region: the cass of Halland, South Sweden & Information Technology and Tourism \\
\hline 137 Ghahramani L, Khallizadeh L., KC B. & 2018 Tour guides' communication ecossystems: an inferential social network analysis approach & Information Technology and Tourism \\
\hline 138 Van der Zee E, Bertocchi D. & 2018 Finding patterns in urban tourist behaviour: a social network anayysis approach based on TripAdvisor reviews & Information Technology and Tourism \\
\hline 139 Sainaghi R, Philips P., Baggo R., Mauri A. & 2019 Hotel performance: Rigor and relevant research topics & Internationa l Journal of Hospitality Management \\
\hline 140 Czernek:MarszalekK. & 2019 Applying mixed methods in social network research - The case of cooperation in a Polish touristdestination & Jounal of Destination Marketing and Management \\
\hline 141 Koffer L, Marcher A, Volgger M, Pechlaner H. & 2018 The special characteristics of tourism innovation networks: The case of the Regiona I Innovation System in South Tyrol & Journal of Hospitality and Tourism Management \\
\hline 142 Jarman D. & 2018 Social network analysis and the hunt for homophily. diversity and equality vithin festival communtites & Journal of Policy Ressearch in Tourism, Leisure and Events \\
\hline 143 Teubner $\mathrm{T}$. & 2018 The web of host-guest connections on Airbnb: a network perspective & Journal of Systems and Information Technology \\
\hline 144 Kirilenko A.P., Stepchenkova S.0, Hernandez.J.M. & $\begin{array}{l}\text { Comparative dustering of destination attractions for different } \\
2019 \text { origin markets with network and spatiala langysyses of on line reviews }\end{array}$ & Tourism Managementr \\
\hline 145 Farmaki A, Khalilzadeh J, Altinay L & 2019 Treve I motivation and demotivation within politically unstable nations & Tourism Management Perspectives \\
\hline
\end{tabular}

